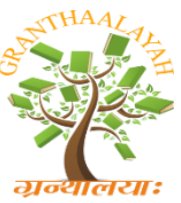

INTERNATIONAL JOURNAL OF RESEARCH GRANTHAALAYAH A knowledge Repository

Science

\title{
REVIEW ON ADOPTION, TREND, POTENTIAL, AND CONSTRAINTS OF RICE PRODUCTION TO LIVELIHOOD IN ETHIOPIA
}

\author{
Tamirat Belayneh $^{* 1}$, Jember Tekle ${ }^{2}$ \\ *1,2 Department of Horticulture and Plant Science, Jimma University, College of Agriculture and \\ Veterinary Medicine P. O. Box 307, Jimma, Ethiopia
}

DOI: https://doi.org/10.29121/granthaalayah.v5.i6.2017.2097

\begin{abstract}
Cultivation of rice in Ethiopia is generally a recent phenomenon it was started first at Fogera and Gambella Plains in the early 1970's, which is preceded by its utilization as a food crop. Hence the present review was to review on adoption, Trend, potential, and constraints of rice production to livelihood in Ethiopia. Although rice was introduced to the country very recently, it has proven to be a crop that can assure food security in Ethiopia. It is reported that the potential rice production area in Ethiopia is estimated to be about thirty million hectares. Since 2006, Ethiopian rice production trends show increases in both area and productivity. Considering the importance and potential of the crop, it has been recognized by the Government as "the new millennium crop of Ethiopia" to attain food security. Rice has become a commodity of strategic significance across many parts of Ethiopia for domestic consumption as well as export market for economic development. Due to the introduction of upland and irrigated rice varieties in the country, rice farming has increased from time to time. There has been twelve upland/lowland NERICAs and Sativa-type, and three irrigated rice varieties released in Ethiopia from 1999 up to 2007. However, Ethiopian rice sector still faces remaining challenges such as high competition with imported rice, poor infrastructure, insufficient mechanization and post-harvest processing technologies, lack of skilled manpower and research facilities, poor marketing infrastructure, and channels. Therefore, building the capacity of the research community, experts, smallholder farmers and the private sector is necessary not only to further increase production but also to improve the quality of rice products through better post-harvest handling and processing.
\end{abstract}

Keywords: Millennium Crop; Adoption; Trend and Livelihood.

Cite This Article: Tamirat Belayneh, and Jember Tekle. (2017). "REVIEW ON ADOPTION, TREND, POTENTIAL, AND CONSTRAINTS OF RICE PRODUCTION TO LIVELIHOOD IN ETHIOPIA." International Journal of Research - Granthaalayah, 5(6), 644-658. https://doi.org/10.29121/granthaalayah.v5.i6.2017.2097. 


\section{Introduction}

Rice (Oryza sativa L.) belongs to the family Poaceae; it is an essential food crop and a major food grain for more than half of the world's population (Liu, L, .2013). It is, a cereal crop, has been gathered, consumed and cultivated by many people worldwide for more than 10,000 years longer than any other crop (Onyango, A., 2014). Global rice cultivation estimated to cover 144 million farms, mostly smaller than 1 hectare. (Connor.D.and Mínguez, M., 2012). In the world, the largest volume of rice production is concentrated in countries China, India, Indonesia, Vietnam, Thailand, Bangladesh, Burma, Philippines, Brazil, and Japan. The percentage share of the above top ten rice producing countries accounts for about 32.9,24.4, 11.0, 7.0, 6.0, 5.4, 5.3 2.9 and $1.8 \%$ of the world production respectively. Ethiopia is $73^{\text {rd }}$ in the world ranking with almost $0.0 \%$ (FAO, 2013).

Rice is an important staple food crop in Africa with a growing demand that poses an economic challenge for the African continent. Annual rice production in Sub-Saharan Africa (SSA) is estimated at 14.5 million metric tons (MT), comprising 15 percent of the region's cereal production. Most of this rice is produced by smallholder farmers. In contrast, Africa's rice consumption is about 21 million MT creating a deficit of about 6.5 million MT per year valued at US\$ 1.7 billion that is imported annually. Overall, imported rice accounts for roughly 40 percent of Sub-Saharan Africa local rice consumption (AATF, 2013). This indicates that the region needs to increase production and productivity to fill the gap between demand and supply created in rice consumption.

Therefore, improving the productivity of rice systems would contribute to hunger eradication, poverty alleviation, national food security and economic development (FAO, 2004). Rice cultivation is the most important activity and source of income for about 100 million households in Asia and Africa (Chakraborty, 2011).just about 20 million farmers in SSA grow rice and about 100 million people depend on it for their livelihoods (Nwanze et al., 2006).During the past three decades, rice grain has seen a steady increase in consumption and demand given its important place in the strategic food security planning policies of many African countries (Africa Rice Center, 2007; Forum for Agricultural Research in Africa, 2009). It is among the important cereal crops grown in different parts of Ethiopia as a food crop. The demand for rice in the country has seen a dramatic increase over the last few years in production and area coverage.

The basis of livelihood of Ethiopia's population is predominantly rural and agricultural. About 82 percent of the Ethiopian population is living in rural areas and engaged in farming for their livelihood (World Bank, 2014). The high population Agriculture is the bastion of livelihood for Ethiopia's population as well as of the economy in general. It provides employment for about $85 \%$ of the active labor force, contributes to more than $45 \%$ of the GDP and $90 \%$ of foreign exchange earnings. Ethiopia has a total land area of about 112.3 million hectares (CSA, 2008). Out of the total land area, about, 74.1 million hectares are suitable for the production of annual and perennial crops (Abera Deressa, 2010). According to Ministry of Economic Development and Cooperation (MEDaC), crop production is estimated to contribute on average about $60 \%$, livestock accounts around $27 \%$ and forestry and other sub-sectors around 13\% of the total agricultural value. 
In spite of the improvement of main macroeconomic indicators in recent years, food security remains as one of the most important issues in Ethiopia's development agenda. In fact, food insecurity in some vulnerable regions is one of the major obstacles to poverty reduction. Both transitory and chronic food insecurity is severe in Ethiopia. Moreover, food insecurity is one of the defining features of rural poverty affecting millions of people particularly in moisture-deficit and pastoral areas (MoFED, 2006). However, the country has been implementing different strategies to achieve food security, Diversification of crops, increasing the availability of food through domestic production, and encouraging the production of early maturing and high yielding crops in different agro-ecologies of the country are some of such strategies rice has become a commodity of strategic significance across many parts of Ethiopia for domestic consumption as well as export market for economic development (Hegde and Hegde, 2013). Besides, rice is among the target commodities that have received due emphasis in the promotion of agricultural production, and as such, it is considered as the "millennium crop" expected to contribute by ensuring food security in Ethiopia. Although rice was introduced to the country very recently, it has proven to be a crop that can assure food security in Ethiopia (MoARD, 2010).

The country has immense potentials for growing rice crop. Rice is grown under widely varying conditions of altitude and climate. It grows from sea level to as high as 3000 meters and it needs a hot and humid climate. It is best suited to regions that have high humidity, prolonged sunshine and an assured supply of water. The area of production of rice in the country has been increasing over the past few years. It is reported that the potential rice production area in Ethiopia is estimated to be about thirty million hectares (MoARD, 2010). Ethiopia has tremendous potential to increase the area under rice and is looking for partnerships to make use of this land (ECRD, March 2012).Gambella, Pawe, Fogera, Metema and Oromia Zone in eastern Amhara National Regional State are suitable for rice production (Gebretsadik, 2004). Out of the total national production of rice in 2008, $40 \%$ is produced in the Amhara regional state, $1.14 \%$ in Tigray region, $0.41 \%$ in Benshangul-Gumz, $7.23 \%$ in Oromia, $1.55 \%$ in Gambella, $13.33 \%$ in Somalia, and $27.18 \%$ Southern region (NRRDSE, 2010).

Hence, Wide production of rice in the country is believed to make a great contribution to food security. Farmers in different parts of the country have shown intense interest in rice production and are frequently requesting for improved rice technologies. Considering the importance and potential of the crop, it has been recognized by the Government as "the new millennium crop of Ethiopia" to attain food security (MoA, 2010).

\section{Literature Review}

\subsection{Rice Crop Global Perspective}

Worldwide rice has been gathered, consumed, and cultivated by women and men for more than 10,000 years - longer than any other crop. Rice crop is the most important food crop for about half of the human race. Global production of rice has increased steadily from around 200 million metric tons (MT) of unmilled rice in 1960 to over 678 million MT in 2009. Rice represents 29\% of the total output of grain crops produced worldwide. Over $90 \%$ of the world's total rice crop is produced in South and East Asia. In area and production, China is the leading country in the 
world. Africa accounts for 3\% of global production (EUCORD, 2012). The major limiting factor for the growth of rice is not climate, but water supply. Rice is the only major crop that can be grown in the standing water in vast areas of flat, low-lying tropical soils and is uniquely adapted for growth in submerged conditions. Rice is grown in the tropical and subtropical regions of most continents. It is cultivated under broadly differing conditions because of the great cultivar diversity. The global rice paddy production and area from the year 2006-2014 and estimate for 2015 is presented in the following figure

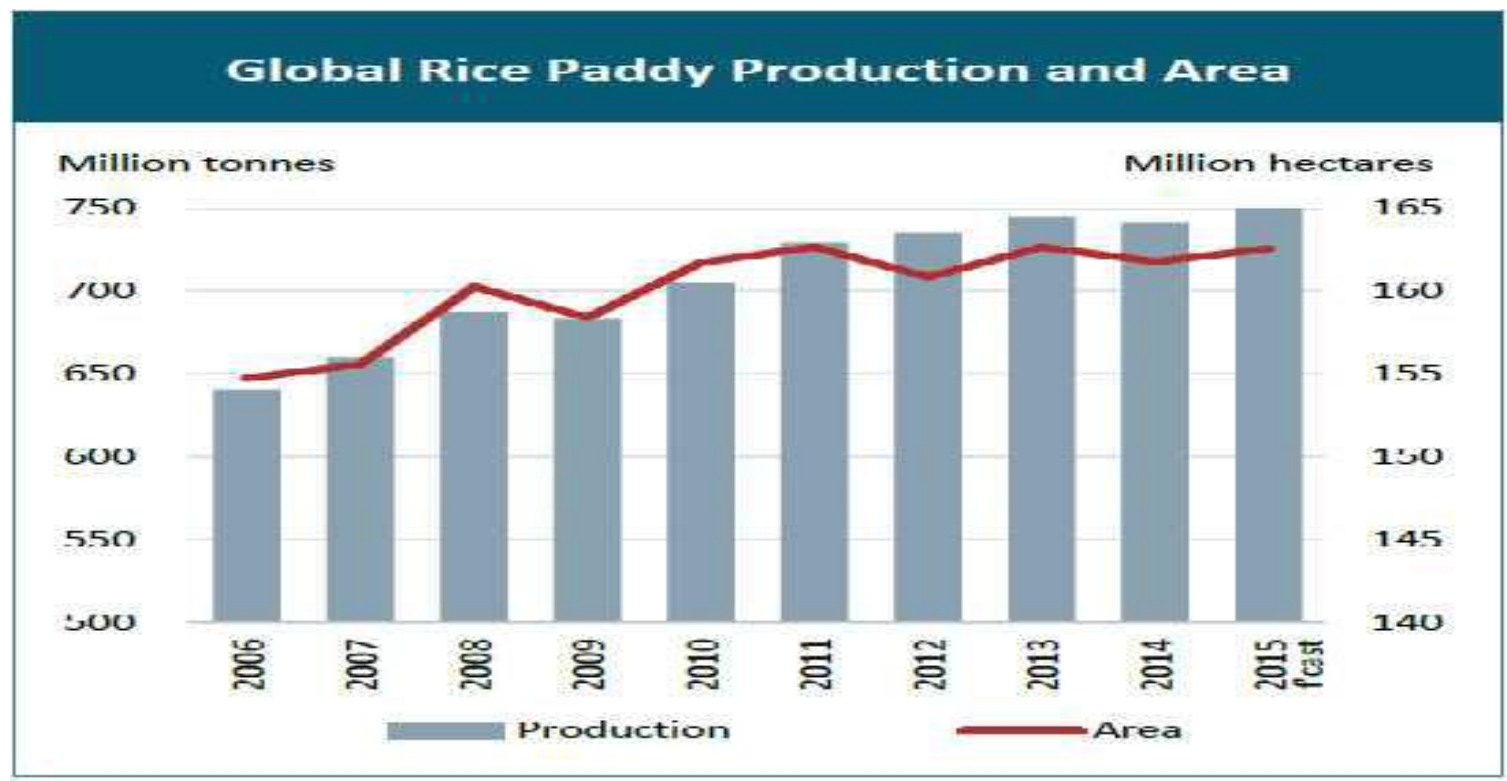

Trends of global rice production and area coverage Source: FAO, 2015

\subsection{Overview of Rice in Africa}

In SSA, agricultural development is important for poverty reduction and food security (World Bank, 2008). Along with the major cereals grown in the region, the importance of rice is now increasing rapidly (Balasubramanian et al. 2007). Rice has become a highly strategic and priority commodity for food security in Africa Consumption is growing faster than that of any other major staple on the continent because of high population growth, rapid urbanization and changes in eating habits (Seck et al., 2013).Africa produces an average of 26.4 million tons of rough rice (tons, milled) in 2012 (FAO, 2013).By 2020, SAA rice paddy production will have increased from 18.4 million tons (Mt) (11.9 Mt of milled rice) in 2010 to $46.8 \mathrm{Mt}$ (30.4 Mt of milled rice), with the productivity improved by research and development activities (Africa Rice, 2011). Rice is becoming an increasingly accepted food in Africa because it is easy to store and cook; it is tasty and can be used for a large variety of dishes. It is grown in more than $75 \%$ of African countries, with a combined population of close to 800 million people.

Africa has adequate land and water resource to produce enough rice to feed its own population and, in the long term, generate export revenues. Rice cultivars, rice-based cropping systems and the rice itself will, however, have to undergo adaptations and improvements in order to meet future demands for both food security of the growing population and environmental conservation (Asch and Brueck, 2010). The challenge posed by climate variability and change is a compelling 
factor in speeding up the innovation process and this requires collaboration among a large number of scientific disciplines and stakeholders. Rice research and development, including market access, will, therefore, have to follow parallel paths (Asch and Brueck 2010). With the current rapid development of rice sector, new actors, and new public-private partnerships are appearing. Many of these actors are not used to working with each other, and opportunities for co-learning and negotiation will need to be explored and evaluated. With more and more actors entering the rice sector in Africa, increasing understanding of the changing roles and patterns of interaction, and how these can be facilitated, will help improve overall system performance (Africa Rice, 2011).

\subsection{Rice Adoption in Ethiopia}

Adoption is defined by different authors in a different fashion. "Adoption commonly refers to the decision to use a new technology or practice by economic units on a regular basis" (Hailu Beyene, 2008). "Adoption is an outcome of a decision to accept a given innovation"(Bonabana, J., 2002).Rogers (1983) defined 'adoption' as use or not- use of a new technology by a farmer at a given period of time. The cultivation of rice in Ethiopia is generally a recent phenomenon, which is preceded by its utilization as a food crop. Some reports have indicated that cultivation of rice in Ethiopia was started first at Fogera and Gambella Plains in the early 1970's. It is believed that a Dutch man introduced rice first in 1973 from Gambella to the Fogera Plain in the Amhara Region (Bekur, 1997). Another author Portuguese, in the sixteenth century, brought rice (Oryza sativa L.) with them for the cultivation of this grain crop in Ethiopia (Huffnagel, 1961).

Other author rice cultivation in Ethiopia is believed to start around 1957 in Metahara, along with the Awash River. Later rice adaptation and screening experiments had been initiated and conducted at Fogera, Gambella, Melkaworer, Debrezeit, and Arbaminch from 1968 to1988 by different organizations (Sewunet, 2005).Gashaw (1989) reported that rice cultivation had probably been started in Ethiopia when the wild rice (0. long staminate) was observed in the swampy and waterlogged areas of Fogera (locally known as zurha) and Gambella plains. So evidence has indicated that cultivation of the crop in Ethiopia was first started at Fogera and Gambella plains in the early 1970's.

Even though, rice was introduced and tested initially at different areas of Ethiopia such as Gambella, Pawe, Woreta in the beginning of 1970s, due attention was not given prior to the mid1990s (Wolelaw, 2005). Since the mid of the 1990s, however, about seven upland rice varieties including four NERICA varieties have been released. Currently, the released varieties, especially, NERICAs, have been under dissemination and expansion in different agroecologies of the country, from lowlands of $750 \mathrm{~m}$ to areas of about $2000 \mathrm{~m}$ elevations by different governmental and non-governmental organizations, In addition, cultivation of rain-fed new rice varieties (NERICA-3 and 4) has been started since 2006 in Oromia Region in Jimma, Iluababora and West Wellega Zones and Southern Nations, Nationalities and Peoples Region (SNNPR) in Hadiya Zone 
Table 1: Rice varieties released and adopted in Ethiopia from 1998 up to 2013

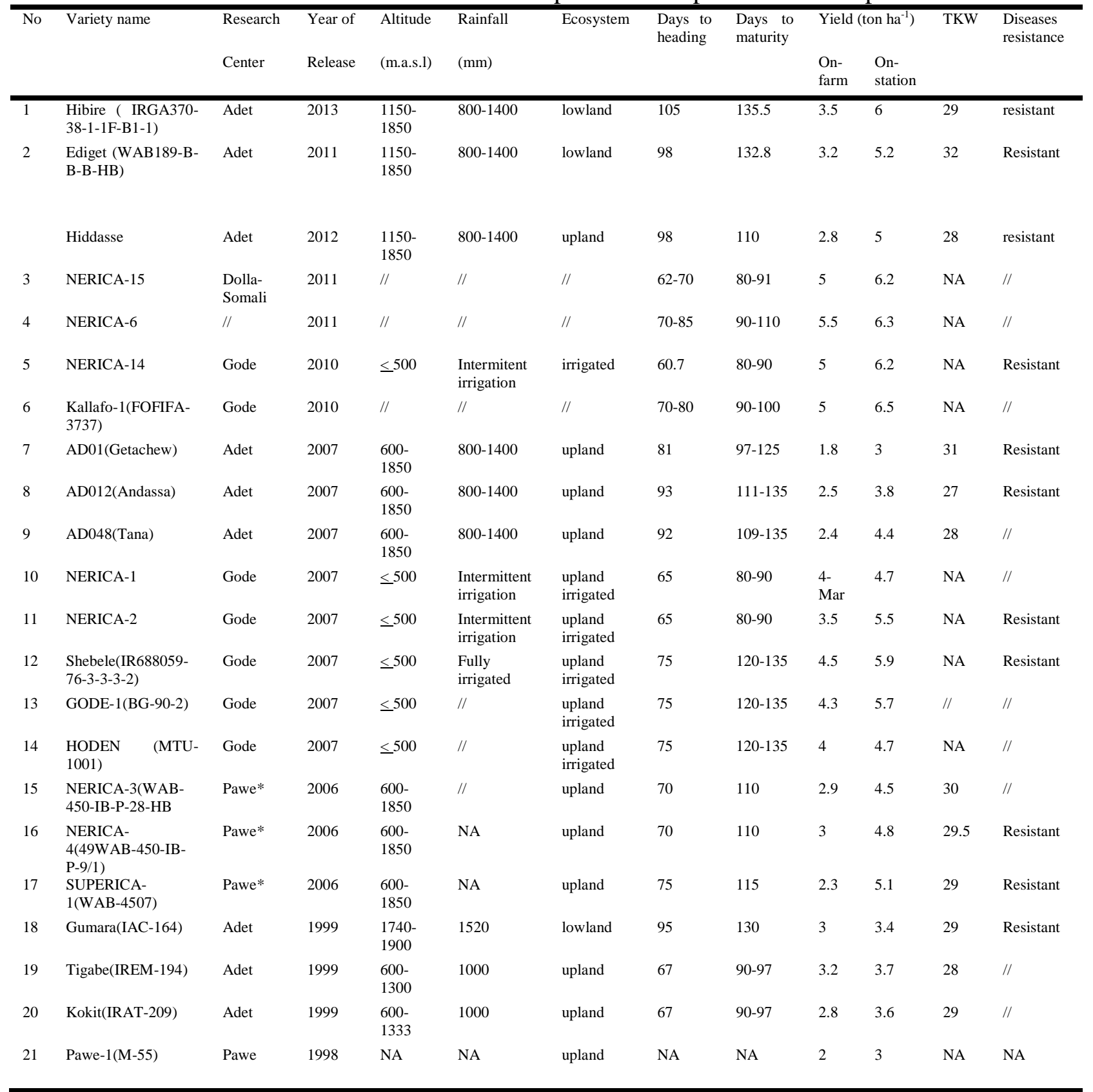

Source (MOA 2014)

\subsection{Prospect of Rice in Ethiopia}

Rice in Ethiopia has big potential to contribute to food security and even to generate foreign currency from its export (Halos-Kim, 2015). Since 2006, Ethiopian rice production trends show increases in both area and productivity. The introduction and expansion of rice production in suitable agro-ecologies could be an option to achieve food security and self-sufficiency. Even though rice is not a traditional staple food in Ethiopia, it is considered a high potential 
emergency and food security crop (Tereke 2006). The trend of rice production is increasing both in area coverage, participant farmers, and production. (MoARD, 2011)

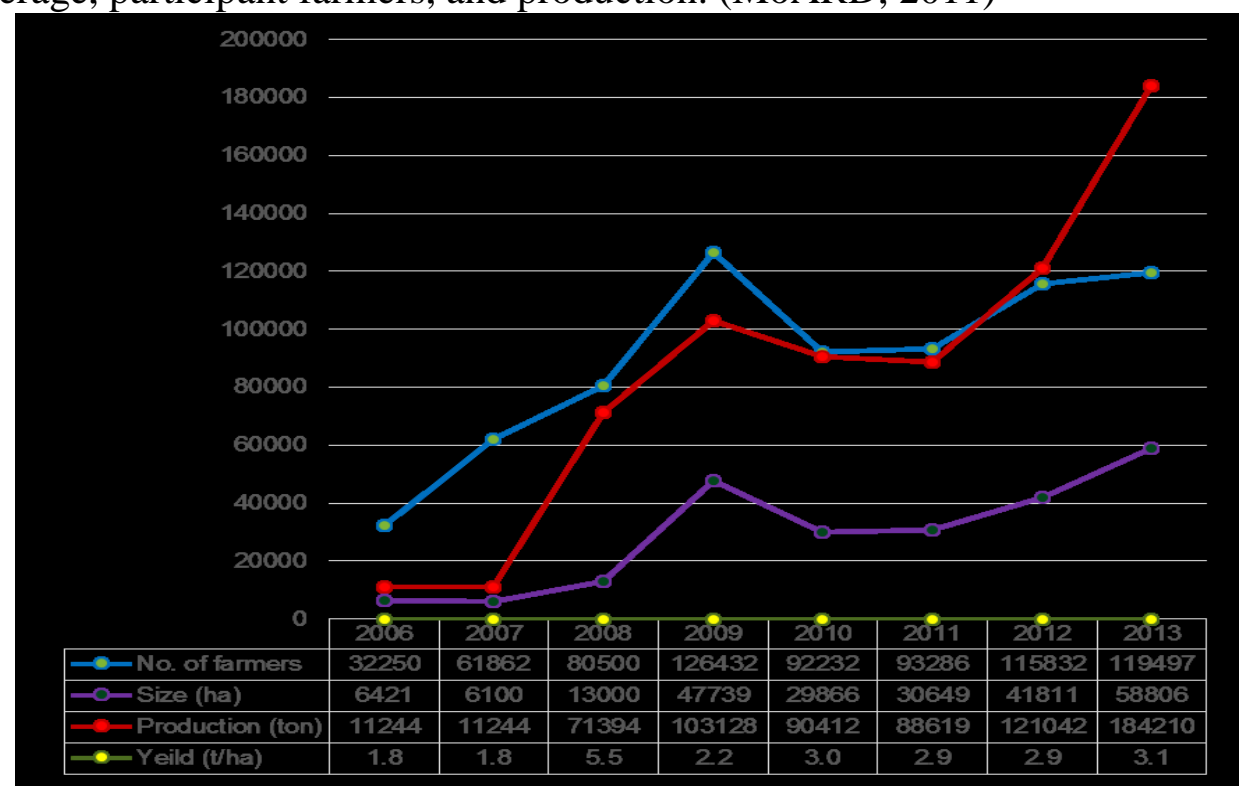

Rice production trend in Ethiopia (Dawit.A 2015)

The trend indicates high increasing rate especially since 2006. Rice producing farmers: increase from 32 thousand in 2006 to 119 thousand in 2013 Area allocated increase from 6 thousand ha in 2006 to 58 thousand ha in 2013, Production increase from 11 thousand tons in 2006 to 184 thousand tons in 2013 (Dawit.A 2015). Total current rice consumption is about 353,998 tons with estimated annual average import of 21,724 tons over the last ten years. Due to the introduction of upland and irrigated rice varieties in the country, rice farming has increased from time to time. There has been twelve upland/lowland NERICAs and Sativa-type, and three irrigated rice varieties released in Ethiopia from 1999 up to 2007 (MoARD, 2010).

\subsection{Potential of Rice in Ethiopia}

According to (MOARD 2010) the production potential for rain-fed rice in the country was assessed using GIS techniques. The parameters considered were rainfall, slope, soil texture, altitude, and temperature. There is about thirty million ha (5.6 million ha highly suitable and about 25 million suitable) for rice production in the country. However, it should be noted that these estimates are based on only the above-stated parameters without field level verification. However (EUCORD 2012) reported that about 17 million hectares of land suitable for rice production, Ethiopia has tremendous potential to increase its rice-growing area and is seeking partnerships to make use of this land. During the Third General Meeting run by the Coalition for African Rice Development (CARD), Ethiopian government recognized that rice can significantly contribute to improving food security and poverty reduction. Rice could suitably grow in many parts of the country, the predominant potential areas are:-West central highlands of Amhara Region (Fogera, Gonder Zuria, Dembia, Takusa and Achefer); North West lowland areas of Amhara and Benshangul Regions (Jawi, Pawi, Metema and Dangur); Gameblla regional state (Abobo and Etang Woredas) South and South West Lowlands of SNNPR (Beralee, Weyito, 
Omorate, Gura Ferda and Menit); Somali Region (Gode); South-Western Highlands of Oromia Region (Illuababora, East and West Wellega and Jimma Zones) (Dawit.A, 2015).

FAO (2009) reported that four rice ecosystems were identified in the country. These are; upland rice, which is grown on naturally drained soils and where the water table always remains below the roots and is entirely rainfed ; Hydro orphic (rainfed lowland ) rice, which is grown on soils where the roots are periodically saturated by fluctuating water table in addition to the rainfall; Irrigated lowland ecosystem, whereby crop water requirement is entirely satisfied from irrigation, and rainfall is not a limiting factor, and Paddy rice (with or without irrigation) which is grown under water-logged or submerged condition.

Table 2: Size of potential area by level of production potential for rain-fed rice (ha)

\begin{tabular}{lllll}
\hline Region & Highly & suitable & $\begin{array}{l}\text { Moderately } \\
\text { Suitable }\end{array}$ & Total \\
\hline Tigray & & $1,278,245$ & 935,565 & $2,213,810$ \\
Afar & 2318 & 147084 & 124158 & 273560 \\
Amhara & 483839 & 5289945 & $2,229,180$ & $8,002,964$ \\
Benishangul & $2,053,332$ & $2,817,944$ & 53,235 & $4,924,511$ \\
Gumuz & & & & \\
Somali & & 69,893 & 375,222 & 445,115 \\
Oromiya & $2,051,787$ & $8,082,388$ & $3,993,068$ & $14,127,243$ \\
Dire Dawa & & 601 & 38,553 & 39,154 \\
Gambela & 373,848 & $2,752,345$ & 38,037 & $3,164,230$ \\
SNNPRR & $\mathbf{6 2 5 , 7 7 1}$ & $4,472,184$ & $1,065,648$ & $6,163,603$ \\
\hline Total & $\mathbf{5 , 5 9 0 , 8 9 5}$ & $\mathbf{2 4 , 9 1 0 , 6 2 9}$ & $\mathbf{8 , 8 5 2 , 6 6 6}$ & $\mathbf{3 9 , 3 5 4 , 1 9 0}$ \\
\hline
\end{tabular}

Source (NRRDSE 2010)

The country is also endowed with huge irrigation potential for rice crop. According to Awulachew et al. (2007), the country has about 3.7 million ha of land suitable for rice crop production.

Table 3: Irrigation potential in Ethiopia by basin

\begin{tabular}{lll}
\hline River Basin & Irrigable land (ha) & Region (s) \\
\hline Tekeze & 83,368 & Tigray and Amhara \\
Abay & 815,581 & Amhara, Oromiya, Benishangul Gumuz \\
Baro-Akobo & $1,019,523$ & Benishangul Gumuz, Gambella, Oromiya, and \\
& & SNNPR \\
Omo-Gibe & 67,928 & SNNPR and Oromiya \\
Rift Valley (Lakes) & 139300 & Oromiya and SNNPR \\
Mereb & 67,560 & Tigray \\
Afar /Danakil & 158776 & Afar Tigray \\
Awash & 134121 & Amhara, Oromiya, Afar, and Somali \\
Wabi-Shebelle & 237,905 & Oromiya, Harari, and Somali \\
Genale-Dawa & $1,074,720$ & Oromiya, SNNPR, and Somali regions \\
\hline \multicolumn{1}{c}{ Total } & $\mathbf{3 7 9 8 ~ 7 8 2}$ & \\
\hline
\end{tabular}

Source: Awulachew et al., 2007 
However, the production of rice is mainly handled by small-scale farmers in a fragmented manner. Similarly, its production trend at the commercial level is minimal and started recently. At present, there is little development regarding private sector involvement in the rice production, where only four commercial farms are registered to produce rice and targeted mainly for the export market. These farms are getting ready to start working with intensive farming and processing technology (Kejela.G, 2011).

Table 4: Commercial Farms of Rice

\begin{tabular}{llll}
\hline No & Company Name & Region & $\begin{array}{l}\text { Acquired Area } \\
\text { production (ha) }\end{array}$ \\
\hline 1 & $\begin{array}{l}\text { Saudi Star Agricultural } \\
\text { Development PLC }\end{array}$ & Gambella & $\begin{array}{l}139,000 \\
\text { (Target 500,000) }\end{array}$ \\
2 & KARUTURI Agro-Products & $\begin{array}{l}\text { Oromia and } \\
\text { Gambella }\end{array}$ & 311,000 \\
3 & PLC & SNNPR & $\begin{array}{l}2000 \\
\text { (Target 5,000) } \\
4\end{array}$ \\
SEKA PLC & SANATE & Gambella & 10,000 \\
\hline
\end{tabular}

Source: MoA, 2010

Introduction and expansion of commercial rice farms provide the country with a number of opportunities and benefits. Development of large rice farms supports efforts geared at attaining food security, and it will help diversify cash and food crops of the country. It increases and/or diversifies sources of foreign currency earnings. On the other hand, the investors participating on rice commercial farms introduce and transfer modern farming technologies, equipment, and skills. It also increases and enhances wage and self-employment opportunities for the community. Moreover, the investors play important role in local infrastructures and social services development. Electric power can also be generated for the local community from rice husk, thus, contributing to the main electric energy. Development of modern commercial farms increase capital accumulations and contribute to the country's overall economic growth. For instance, at present time Saudi Star Agricultural Development Plc at Alwero rice farm in Gambella is distinctive for carrying out all activities of production, processing, polishing, and standardization of rice under the same management. The factory has the capacity to dry 400 tons of rice and process 350 tons per day and generates its own power from the rice bi-product. The company also owns another factory with a capacity of polishing 350 tons per day of rice in Bishoftu town, $45 \mathrm{~km}$ south Addis Ababa (TIRET 2016)

\subsection{Rice Production in Ethiopia}

Rice production in Ethiopia has started a few decades ago and now the country is proved to have reasonable potential to grow different rice types for rainfed lowland, upland, and irrigated ecosystems. Rice is currently considered as a strategic food security crop and its use as a food crop, income source, employment opportunity and animal feed has been well recognized in Ethiopia (Teshome and Dawit, 2011). However, its importance is being well recognized in the country as the area coverage of 18,000 ha and total production of 42,000 tons in 2006 has increased in 2009 to 155,000 ha and 496,000 tons, respectively (MoARD, 2010). The demand for improved rice technologies is increasing from time to time from different stakeholders. This, 
therefore, calls for the need to establish a strong research and development system to bring about productive, sustainable, stable, and profitable rice farming system in the country. Whereas the previous four years the total cultivated area at the national level has increased from 30,649 in $2011 / 2012$ to $41,811.97$ hectares in 2012 / 2013. The cultivated area has increased in $2012 / 13$ as compared to $2011 / 2012$ by about $36.42 \%$ nationally with a considerable difference across regions. Accordingly, in the last two years, rice production has increased from a total of 886,158 quintals, in $2011 / 12$ to $1,210,415$ quintal in 2012/13. While productivity in quintal per hectare has increased from 28.91in 2012 to 28.97 and the number of participant farmers increased from 115,832 to 119, 4970 in 2013 cropping season CSA (2014). However rice remains as a minor crop in Ethiopia both in area coverage and production compared to a large area and favorable agro-climatic conditions, the country has immense potential for expanding rice production.

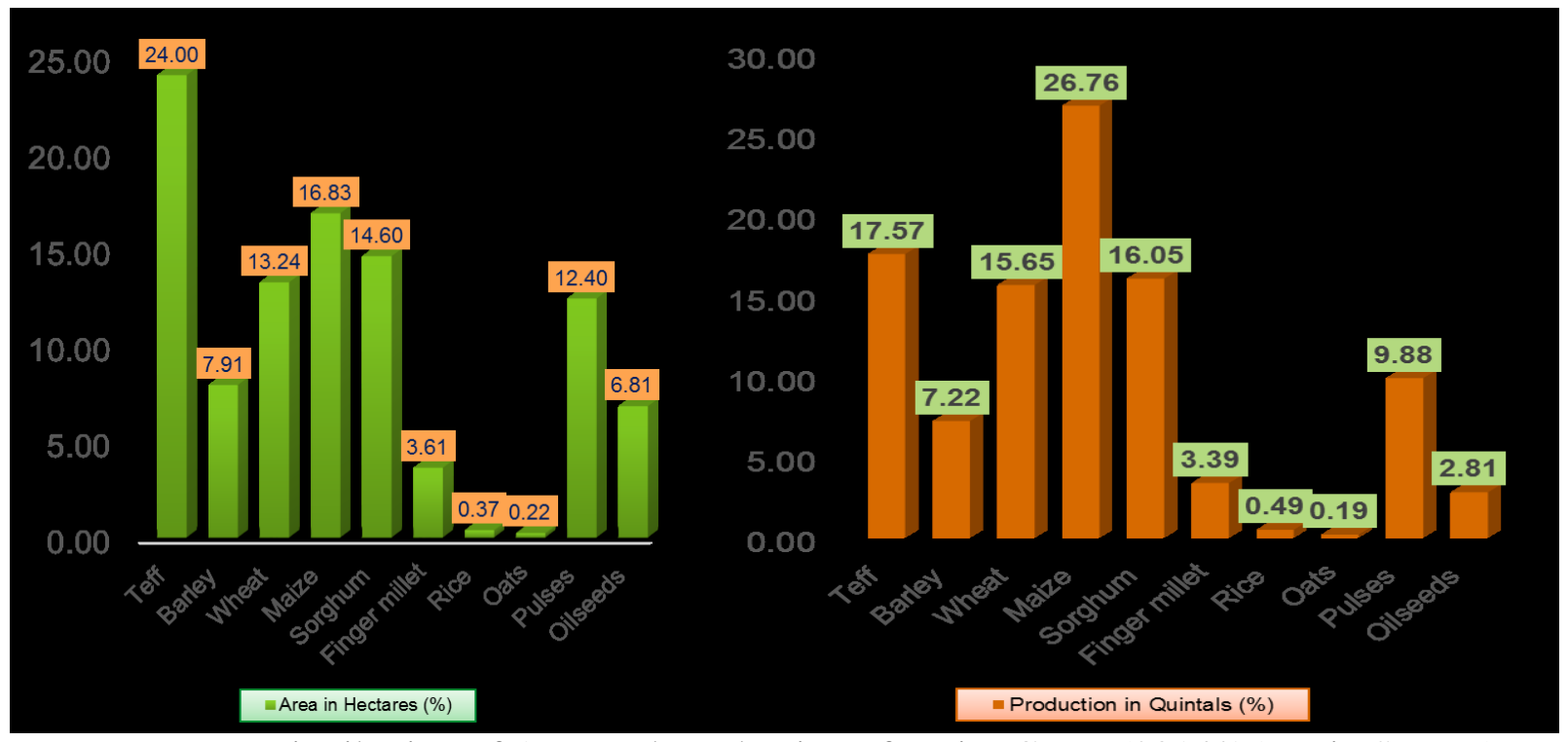

Percentage Distribution of Area and Production of Major Crops (2014/15 Main Season) Source (Dawit.A, 2015)

\subsection{Situation to Increase Rice Production}

\subsubsection{Food Price Hike and Government Actions}

According to (Odi, 2008) reported that the food prices have been rising since the early 2000s, and spiked in the years 2007-2008.The food prices hike in 2007-2008 was the biggest spike on world food markets. The price hike was mainly for three of the world's major cereals (rice, wheat, and maize) the price of a ton of wheat climbed from $\$ 105$ in January 2000, to $\$ 167$ in January 2006, to $\$ 481$ in March 2008). The crises were leading to substantial effects on the poor in countries where rice is the staple food for consumers. As FAO (2010) estimated that the poor people often spend as much as $40 \%$ of their incomes on staple foods. Governments of Ethiopia in collaboration with other actors responded to the crises by taking the following actions: Recognize rice as one of the millennium crops, Promotion of Private sector investment in rice production (e.g. Land allocation for private investors) Promotion of improved rice technologies, Irrigation Development Increase area of rice production due to high rice price. 


\subsubsection{Market Demand and Availability of Rural Labor}

According to (Dawit.A, 2015) reported that Higher cost value of rice grains over other cereals; increased rice consumption habit of consumers along with income increase and urbanization (Demand Increase); Integration of Rice value chain through improved processing (promotion of quality machineries) and integration of value chain actors (ensuring service provision by private sector)The above demand factors have driven Ethiopian smallholder farmers to start rice production this shift of cropping was enabled also by the abundant and low-cost rural labor, as the rice crop is labor intensive.

\subsubsection{Technology, Inputs, and Research}

Availability and the use of high yielding and adaptable rice varieties; Introduction and utilization of improved farm mechanization technologies; Adoption of various promotion approaches, such as community-based seed multiplication, pre-scaling up of technologies, and on-farm demonstration (Dawit.A, 2015).

\subsubsection{Suitability Related Factors}

Ethiopia has the existence of huge unexploited lands and diverse ecosystems such as the uplands, rain-fed lands and flashes flood prone areas (during the rainy seasons) Long shelf life and acceptance of rice amongst rural population due to the possibility of using rice to a range of traditional food recipes. Relatively higher productivity as compared to other main staple crops Possibility of using in a range of traditional food recipes Provide by-products such as straws and husks that shall be fed to livestock and/or used as an alternate source of fuel (Dawit.A, 2015).

\subsection{Constraints Associated with Rice Production}

Constraints for Sustainable increased production and productivity abound, however: poor access to improved rice varieties, especially for irrigated rice, and limited participation of seed growers in the production and marketing of rice seed; poor access and use of modern postharvest techniques and equipment; grassy weeds and insect pests; limited access to credit; shortage of labor, specifically during periods of intensive weeding; poor knowledge of producers and other market actors about rice product quality; excessive numbers of intermediaries, and price seasonality; and finally, inadequate storage (EUCORD 2012).

\subsection{Livelihood of Rice in Ethiopia}

Rice has become a commodity of strategic significance in Ethiopia for domestic consumption as well as export market for economic development (Hegde and Hedge, 2013). Besides, rice is among the target commodities that have received due emphasis in the promotion of agricultural production, and as such, it is considered as the "millennium crop" expected to contribute to ensuring food security in Ethiopia. Although rice introduced to the country very recently, it has proven to be a crop that can assure food security in Ethiopia, the second most populous nation in SSA (MoARD, 2010). As a food crop, rice has some inherent characteristics which make it attractive, in particular for small-scale farmers as well as for the urban poor and rich. Rice fits 
easily into the lifestyles of the people especially to prepare different dishes like injera which is the common food of Ethiopians. In most cases, rice is eaten in the form of injera lonely or in combination with other food crops like sorghum and teff. Rice was also cooked by boiling in water, steaming or frying and is eaten. It is also eaten in the form of kita, Porridge (gonfo) and bread (dabo). It was also used for local drinks like tella, even though; most of the farmers talk about its strong for drinks that could bring a headache. Furthermore, rice has some inherent characteristics which make it attractive that can available all year round because of its long shelflife, making it preferable to other crops for food security( Hadash .H 2015). Rice production has brought a significant change in the livelihood of farmers and created job opportunities for a number of citizens in different areas of the country. For instance, the study of Berhanu and Dirk (2007) on Fogera woreda indicated that $72 \%$ of the households are producers of rice and about $50 \%$ of the farmers sell rice in the area. Similarly, Meron A. 2016 reported that the cost-benefit analysis of rice production at Fogera district shows that rice production is a profitable business for farmers. She further states that farmer obtained net profit of Birr 11,890.40 per hectare.

\section{Summary and Conclusion}

Rice is the staple food crop for more than half of the world population. It was introduced to Ethiopia in the beginning of the 1970s, even though much attention was not given to it prior to the 1990s. Currently, Rice varieties, especially, NERICAs have been under dissemination and expansion in different agro-ecologies of the country with no sufficient information on the yield stability of these varieties. The cultivation of rice in Ethiopia is generally a recent phenomenon. However, the adoption of rice as a potential crop is gradually increasing both in numbers of farmers adopting the crop and in the land of production. The potential rice production area in Ethiopia is estimated to be about thirty million hectares while rice remains as a minor crop in Ethiopian Agriculture. The demand for improved rice technologies is increasing from time to time from different stakeholders. This, therefore, calls for the need to establish a strong research and development system to bring about productive, sustainable, stable, and profitable rice farming system in the country. Given the high consumption increase and the food price hike, the government of Ethiopia has given greater attention to rice, considering it as a 'Millennium crop' , placed a set of policies to attract private sectors and resulted in some private investment and increased the investment on infrastructure, rural finance, access to improved technologies, and Research and Development for rice production. Demand increase and the high price of rice converted farmers to rice production thus the number of rice farmers and area of rice cultivation increased to a great extent. As a result of these interventions, Ethiopia achieved remarkable rice production growth in a short period of time. However, the Ethiopian rice sector still faces remaining challenges such as high competition with imported rice, poor infrastructure, insufficient mechanization and post-harvest processing technologies, lack of skilled manpower and research facilities, poor marketing infrastructure, and channels. Building the capacity of the research community, experts, smallholder farmers and the private sector is necessary not only to further increase production but also to improve the quality of rice products through better postharvest handling and processing. 


\section{Future Line of Work}

As it is already discussed rice is introduced to Ethiopia recently and, the country has immense potentials for growing rice crop and suitably grows in many parts of the country. The availability of tremendous potential to enhance rice production including about 5 million ha of highly suitable and about 24 million ha of suitable land, and the untapped water resources for irrigated rice production. Besides this the existing natural resources (water and fertile soil), the government has given more emphasis on the development of rice production to reduce poverty, however, rice doesn't have a well-institutionalized production system and the production of rice is mainly handled by small-scale farmers in a fragmented manner. Consequently, its farming techniques, agronomical practices, harvesting, and processing technologies have followed the local knowledge, practice and available tools and implements. In this regard, it still requires effort, time and resource in disseminating the appropriate skill, technologies, and knowledge, for better production, productivity, and utilization of the product.

There is still huge potential to increase rice production and to improve the livelihood of the rice producers. There is greatly increased awareness that rice has become a strategic commodity to fuel economic growth and to contribute toward hunger and poverty reduction across the continent. Many African countries have embarked on ambitious programs to boost their rice production capacity good practices should be identified and examples of successful agricultural development should be publicized, that is, the agricultural models that will lead to sustainable development must be prioritized, if Ethiopia is to be food secure research in this area should be intensified and it should target crops with high economic potential such as rice. Farmers confronted with weather vagaries or climate change should be assisted by the government in the improvement of irrigation systems. NERICA rice variety can have a strong impact on the livelihoods of Ethiopians. Detailed characterization of NERICA varieties is therefore required to support farmers' decision making. Agronomic and post harvest technology packages should be developed or released in order to enhance performance and quality. Prerequisites for enabling technologies such as NERICA to raise food security in the country include farmers having improved access to seed and information as well as favorable policies supporting the development of agricultural sector. Policy decisions should focus on rice price stability as an important long-term objective, although the measures to achieve it need to vary with changes and shocks in production and trade.

NGOs should be giving more attention to the rice sector than ever before as important intervention areas to support the smallholder farmers and other value chain, actors. This will give farmers the opportunity to access improved technologies and capacity building (training on good agronomy practices) and processors to upgrade their processing technologies. These institutional changes will provide good opportunity to create increasing demand and competitive market for quality rice. This will, in turn, result in endogenous technological change and overall development in the rice sector. Similarly, high productivity of the crop and high market demand were also some of the opportunities of the crop. 


\section{Acknowledgment}

First of all, I would like to give thanks to the Almighty God who gave me a chance to undertake this study to the successful accomplishment of my seminar paper. Also, I would like to express my sincere gratitude to my advisor Aduagnaw Mintesenot (Ph.D.) for his intellectual and professional guidance and commitment, follow-ups and tireless efforts in giving advice throughout the period of this study. Last but not least, I like to express my most heartfelt thanks to classmates for their wonderful encouragement during my studies.

\section{References}

[1] Abera, D., 2010. Accelerated Growth in Ethiopia Agriculture. MoA, Addis Ababa, Ethiopia.

[2] Africa Rice, 2011.Boosting Africa's Rice Sector Research for development strategy 2011-2020

[3] African Agricultural Technology Foundation, 2013.Nitrogen use efficiency, water use efficiency and salt tolerant rice project.

[4] Asch, F. and Brueck, H., 2010. Rice crop innovations and natural-resource management A glimpse into the future. In 2nd Africa Rice Congress: Innovations and Partnerships to Realize Africa Rice Potential, March (pp. 22-26).

[5] Awulachew SB, Yilma AD, Loulseged M, Loiskandl W, Ayana M. Alamirew T. 2007. Water Resources and Irrigation Development in Ethiopia. Colombo, Sri Lanka: International Water Management Institute. 78p. Working Paper 123.

[6] Balasubramanian, V., Sie, M., Hijmans, R.J. and Otsuka, K., 2007. Increasing rice production in sub-Saharan Africa: challenges and opportunities. Advances in Agronomy, 94, pp.55-133.

[7] Bekur. 1997. Rice Production at the Fogera Plain. Magazine of the Amhara National Region State Culture, Tourism and Information Bureau (Amharic Version) No-3.

[8] Berhanu, G. and Dirk, H., 2007. Cereal marketing and household market participation in Ethiopia: the case of Teff, Wheat, and Rice. In AAAE Conference Proceedings (pp. 243-252).

[9] Central Statistical Authority (CSA, 2008). Ethiopia, Statistical Abstract, Addis Ababa

[10] Chakraborty, (2011), Rice production and productivity in Andhara Pradesh, Report Prepared as part of the Summer Internship for Masters in Development Studies, Tata Institute of Social Studies, Muba

[11] Connor, D.J., and Mínguez, M.I., 2012. Evolution not revolution of farming systems will best feed and green the world. Global Food Security, 1(2), pp.106-113.

[12] CSA (Central Statistical Agency). 2014. Agricultural sample survey Report on area and Production of major crops. Central Statistical Agency of Ethiopia, Addis Ababa, Ethiopia.V.1. Statistical bulletin.532

[13] Dawit Alemu 2015 Rice in Ethiopia: Progress in Production Increase and Success Factors 6th CARD General Meeting Ethiopia institute of agriculture research

[14] Ellis, W., Lomax, J., and Bouman, B., 2014. The role of voluntary sustainability standards in South-South food commodity supply chains: the case of the sustainable rice platform. Voluntary Standards for Sustainable Food Systems: Challenges and Opportunities, p.187.

[15] Esayas Kebede. 2009. Agricultural commercialization in Ethiopia. A paper presented on SGA, workshop. ECA, Addis Ababa, Ethiopia

[16] EUCORD (European Cooperative for Rural Development), 2012. Rice sector development in East Africa, a desk study prepared for the Common fund for commodities.

[17] FAO 2013. Rice Market Monitor. Food and Agriculture Organization of the United Nations.Volume XVI-Issue No. 1.

[18] FAO. 2004. Production Yearbook. Vol.50. Rome

[19] FAO. 2015, Rice market monitor. Vol. XVI1I: Issue No. 1. 
[20] FARA (The Forum for Agricultural Research in Africa).2009. Patterns of change in rice ProductioninAfrica:Implicationforricepolicydevelopment/Ministerial_Policy_brief_series_No_2.

[21] FARA, 2009. Patterns of change in rice production in Africa. Implications for rice policy development. Ministerial Policy Brief Series Number 2, Accra, Ghana, pp: 1-7.

[22] Gashaw Asfaw, 1989.Rice production in Ethiopia (Amharic version). Addis Ababa, Ethiopia.

[23] Gebretsadik, Z., 2004.The response of Upland Rice (Oryza sativa L.) to Nitrogen and Phosphorus Fertilizer Applications in Oromia Zone of Amhara Region (Doctoral dissertation, MSc Thesis (Unpublished). Alemaya University, Ethiopia.).

[24] Halos-Kim, L., 2015. Value-addition, agro-enterprises, partnerships \& market access. African Journal of Food, Agriculture, Nutrition and Development, 15(5).

[25] Hegde, S. and Hegde, V., 2013.Assessment of global rice production and export opportunity for economic development in Ethiopia. Int. J. Sci. Res, 2, pp.257-260.

[26] Kejela Gemtessa. 2011. Mapping of Poverty Reduction Strategy Papers (PRSP), Sector Strategies and Policies Related to Rice Development in Ethiopia, Coalition for African Rice Development (CARD): Addis Ababa, Ethiopia.p.24.

[27] Liu, L., Waters, D.L., Rose, T.J., Bao, J. and King, G.J., 2013. Phospholipids in rice: significance in grain quality and health benefits: a review. Food Chemistry, 139(1), pp.1133-1145.

[28] Ministry of Finance and Economic Development Ethiopia (MoFED), 2006: Building on Progress a Plan for Accelerated and Sustained Development to End Poverty (PASDEP), Addis Ababa, Ethiopia

[29] MoARD (Ministry of Agriculture and Rural Development). 2010. National Rice Research and Development Strategy Of Ethiopia. Addis Ababa, Ethiopia

[30] MoARD. 2011.Towards implementation of National Rice Research and development Strategy of Ethiopia

[31] Mulugeta, S., 1999. Rice: Potential crop for food security in Amhara Region. Agric-Topia: Q. Newslett. Ethiop. Agric. Res. Org, 14, pp.1-3.

[32] Nwanze, K. F., Mohapatra, S., Kormawa, P., Keya, S., \& Bruce-Oliver, S. (2006). Rice development in sub-Saharan Africa. Journal of the Science of Food and Agriculture,86, 675-677.

[33] Onyango, A.O., 2014.Exploring options for improving rice production to reduce hunger and poverty in Kenya. World Environment, 4(4), pp.172-179.

[34] Seck, P.A., Toure, A. A., Coulibaly, J. Y., Diagne. A. and Wopereis, M. C. S. (2013). The impact of rice research on income, poverty and food security in Africa: an ex-ante analysis. In: Wopereis, M. C. S., Johnson, D. E., Ahmadi, N., Tollens, E., and Jalloh, A. (Eds.), Realizing Africa's Rice Promise. CABInternational, Wallingford, UK. pp. 24-33.

[35] Tareke, B., 2003. Rice: A high potential emergency and food security crop for Ethiopia.SG2000.

[36] Teshome, N. and Dawit, A., 2011. An Overview of the National Rice Research and Development Strategy and its Implementation. Challenges and Opportunities of Rice in Ethiopian Agricultural Development, pp.1-16.

[37] The World Bank. 2009. Project Appraisal Document for Eastern Africa Agricultural Productivity Program APL1 in support of the first phase of East Africa Agricultural Productivity Program

[38] Wolelaw S., 2005. Factors Determining Supply of Rice: A Study in Fogera District of Ethiopia. Msc. Thesis. Haramaya University, School of Graduate Studies. Haramaya, Ethiopia

[39] World Bank (2014). World Development Indicators 2014. World Bank Publications.

*Corresponding author.

E-mail address: tamiratbelayneh@gmail.com 